\title{
Weeds in soybean crop after annual crops and pasture
}

\section{Ricardo Fachinelli ${ }^{1}$, Thais Stradioto Melo ${ }^{2}$, Denise Prevedel Capristo ${ }^{1}$, Hadassa Kathyuci Antunes de Abreu', Gessí Ceccon ${ }^{3}$}

${ }^{1}$ Universidade Federal da Grande Dourados, Dourados, Mato Grosso do Sul, Brasil. E-mail: rfachinelli@hotmail.com, denise_prevedel@hotmail.com, hadassa.antunes@gmail.com

${ }^{2}$ Universidade Federal de Pelotas, Pelotas, Rio Grande do Sul, Brasil. E-mail: thais.stradioto1 @ gmail.com

${ }^{3}$ Embrapa Agropecuária Oeste, Dourados, Mato Grosso do Sul, Brasil. E-mail: gessi.ceccon@embrapa.br

Received: 02/10/2020; Accepted: 07/12/2020.

\begin{abstract}
The use of crop practices to reduce the weed community is an ally to integrated weed management. Given this, the study aimed to identify a composition and weed infestation in a soybean area under different predecessor crops implanted in different years. The experiment was carried out in the 2019/2020 harvest in Dourados, MS. The experimental design was a randomized block with nine treatments. The treatments were composed of autumnwinter crops. The area with predecessor cultivation: corn-Brachiaria intercropping; cowpea beans; single corn; an area with predecessor cultivation of Brachiaria as pasture for one year; two years; three years; four years; five years, and six years. All treatments were followed by soybean cultivation in the 2018/2019 harvest and an intercropping with corn and Brachiaria in the 2019 off-season harvest. There was a difference in the absolute weed infestation between the evaluated areas. Treatments with corn and cowpea had greater weed infestation. However, areas with pasture or intercropping with corn and Brachiaria showed less infestation, especially in areas with Brachiaria grown in the off-season for more than two years. The weed species composition differs between the areas evaluated. The implantation of a corn-Brachiaria intercropping in the off-season under a crop rotation system, especially in areas with Brachiaria grown in the off-season for more than four years, reduces the weed infestation.
\end{abstract}

Keywords: Phytosociology, Weed community, Crop rotation, Glycine max.

\section{Plantas daninhas na cultura da soja após culturas anuais e pastagem}

\section{RESUMO}

O uso de manejos culturais a fim de reduzir a comunidade de plantas infestantes é um aliado ao manejo integrado de plantas daninhas. Em vista disso, objetivou-se identificar a composição e a infestação de plantas daninhas em área de soja sob diferentes culturas antecessoras implantadas em diferentes anos. O trabalho foi realizado na safraverão 2019/2020, em Dourados, MS. O delineamento experimental foi o de blocos casualizados, com nove tratamentos. Os tratamentos foram compostos pelos cultivos de outono-inverno: área com cultivo antecessor de: consórcio milho-braquiária; feijão caupi; milho solteiro; área com cultivo antecessor de braquiária como pasto por 1 ano; 2 anos; 3 anos; 4 anos; 5 anos e 6 anos. Todos esses tratamentos foram sucedidos pelo cultivo de soja na safra 2018/2019 e com consórcio de milho-braquiária na safrinha 2019. Houve diferença na infestação absoluta de plantas daninhas entre as áreas avaliadas. Os tratamentos em que havia milho e feijão-caupi apresentaram maior infestação de plantas daninhas, entretanto, as áreas em que havia pastagens ou consórcio milho com braquiária apresentaram infestação menor, especialmente nas áreas com braquiária cultivada na safrinha por mais de dois anos. A composição de espécies daninhas difere entre as áreas avaliadas. A implantação de consórcio milho-braquiária na safrinha em sistema de rotação de culturas, especialmente nas áreas com braquiária cultivada na safrinha por mais de quatros anos, reduzem a infestação de plantas daninhas.

Palavras-chave: Fitossociologia, Comunidade infestante, Rotação de culturas, Glycine max. 


\section{Introduction}

The use of vegetation cover is an important tool in the integrated management of weeds, as they can reduce and alter the weed community, besides minimizing or extinguishing the use of chemical control (Martins et al., 2016). This vegetation cover can be introduced in the production system using crops like corn and cowpea, pastures, or intercropping use, such as corn-Brachiaria (Silva et al., 2018; Seidel et al., 2015; Melo et al., 2019).

The predecessor crop, such as intercropping and croplivestock integration associated with the no-till system, favors the subsequent crop competing with weeds (Concenço et al., 2012; Gontijo Neto, et al., 2014). Melo et al. (2019) reported that the association between corn and Brachiaria cultivated with reduced spacing promoted a greater reduction in weeds occurrence in the subsequent soybean crop. Another positive point is the change in the soil seed bank (Sodré Filho et al., 2004).

Since the infesting species community ranges according to predecessor cultures, it is essential to identify the species and methods that assist in the knowledge of these communities. Identifying weed species is paramount in preventing possible losses caused by competition between invasive species and the economic interest crop (Nordi and Landgraf, 2009).

Among the methods of assessing weed infestation, phytosociology allows estimating the density, frequency, and dominance of each plant species in the weed community and, therefore, determining their importance in agricultural areas (Barbour et al., 1998). Through this tool, it is possible to have the weed community representative knowledge and thus make weed control decision-making more efficient.

Given the above, it is necessary to study and understand the use of different predecessor crops and their contribution to the management of weeds for the subsequent crop. Thus, this study aimed to identify the composition and weed infestation in a soybean area under different predecessor crops implanted in different years.

\section{Material and Methods}

The experiment was carried out in the 2019/2020 summer harvest, at Embrapa Agropecuária Oeste, Dourados, MS, located at $22^{\circ} 16^{\prime}$ 'S and $54^{\circ} 99^{\prime} \mathrm{W}$ and 408 meters of altitude. The region climate is classified as Tropical Monsoon (Am-type) according to KöppenGeiger. The soil was classified as a Latossolo Vermelho distroférrico, with a very clayey texture (Santos et al., 2018). The results of the soil chemical analysis in the $0.00-0.20$ m layer are: $\mathrm{Al}=0.03 \mathrm{cmol}_{\mathrm{c}} \mathrm{dm}^{-3} ; \mathrm{pH}\left(\mathrm{CaCl}_{2}\right)$ $=5.35 ; \mathrm{OM}=31.23 \mathrm{~g} \mathrm{~kg}^{-1} ; \mathrm{P}($ Mehlich $)=34.48 \mathrm{mg} \mathrm{dm}^{-}$ 3; $\mathrm{K}=0.79 \mathrm{cmol}_{\mathrm{c}} \mathrm{dm}^{-3} ; \mathrm{Ca}=5.74 \mathrm{cmol}_{\mathrm{c}} \mathrm{dm}^{-3} ; \mathrm{Mg}=1.54$ $\mathrm{cmol}_{\mathrm{c}} \mathrm{dm}^{-3}$ and base saturation $=64.75 \%$. Rainfall and maximum and minimum temperatures data during the evaluation period are shown in Figure 1.

The experimental design used was randomized blocks with nine treatments and four replications. The treatments were composed of the autumn-winter crops in the different years: T1: predecessor cultivation of cornBrachiaria intercropping; T2: predecessor cultivation of cowpea (Vigna unguiculata L. Walp); T3: predecessor cultivation of single corn; T4: predecessor cultivation of Brachiaria for one year; T5: for two years; T6: for three years; T7: for four years; T8: for five years; T9: for six years. After these treatments, the entire area was cultivated with the corn-Brachiaria intercropping in autumn-winter 2019 and soybean in the 2019/2020 harvest, where weed evaluations were carried out.

The plots were three meters wide, and five meters long, with the soybean rows spaced $0.45 \mathrm{~m}$ apart. At 30 days before sowing, the plants in the area were desiccated with $1.4 \mathrm{~L} \mathrm{ha}^{-1}$ glyphosate. The BRS 1003 IPRO soybean cultivar was sown on November 12, 2019, over the previous crop straw, with $0.45 \mathrm{~m}$ row spacing.

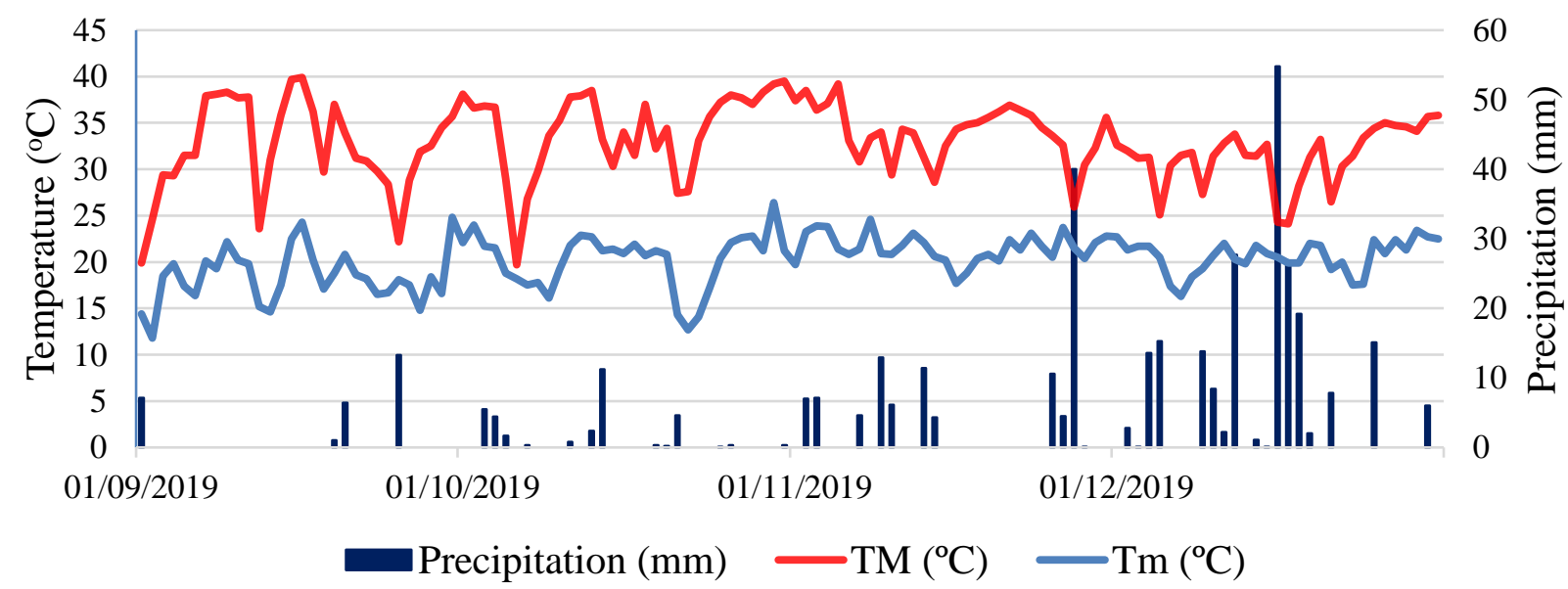

Figure 1. Precipitation, maximum (TM) and minimum (Tm) temperature during the experimental period in Dourados, MS (2019). Source: Embrapa Western Agriculture (2019). 
In the V3-V4 phenological stage of soybean, the weed community phytosociological characterization of the crop was carried out through random sampling within each plot, using the Random Squares sampling method proposed by Barbour et al. (1998). A metallic square (0, $5 \mathrm{~m} \times 0.5 \mathrm{~m}$ ) was used to collect one square by replication, with all plants in this area identified, counted, and collected. Subsequently, the samples were placed in an oven until reaching constant mass to determine the dry mass. For each species, relative density (DE), relative frequency $(\mathrm{RF})$, and relative dominance (DO) were obtained.

The density expresses the number of plants of each species that occurs in each treatment, describing the species ability to generate offspring, according to equation 1: $r D E=\frac{I}{T I} * 100$.

Where DE: relative density (\%); I: number of individuals of the $\mathrm{x}$ species in the area; TI: total number of individuals in the area.

The frequency expresses the species distribution in the evaluated area, whether in localized spots or a generalized manner, and is determined by equation 2 : $r R F=\frac{Q}{T Q} * 100$.

Where: RF: relative frequency (\%); Q: number of samples evaluated in the treatment, in which the $\mathrm{x}$ species is present; TQ: total number of samples in the treatment.

Dominance expresses the species ability to occupy the physical space and inhibit the growth of the others; that is, the most dominant plant is the one that covers the largest area of the soil and accumulates the greatest mass, being determined by equation 3: $r D O=\frac{D M}{T D M} * 100$.

DO: relative dominance (\%); DM: the dry mass of the species in the treatment, TDM: the total dry mass of weeds in the area.

The importance value (IV) is the arithmetic mean of the parameters DE, RF, and DO, and the importance value index of each species, in each treatment, was obtained according to Pandeya et al. (1968) and Barbour et al. (1998), using equation $4: I V=\frac{r D E+r R F+r D O}{3}$.

The areas were also intra-analyzed for species diversity using the Simpson (D) and Shannon-Weiner (H') indexes (Barbour et al., 1998), and the ShannonWeiner Evenness Proportion (SEP) sustainability coefficient was determined according to McManus and Pauly (1990), where:

Simpson diversity coefficient (D) quantifies, in simple terms, the probability that two individuals randomly collected in the same area belong to the same species using equation $5: \mathrm{D}-1=\frac{\sum \mathrm{ni} *(\mathrm{n} 1-1)}{\mathrm{N} *(\mathrm{~N}-1)}$.

The Shannon-Weiner diversity coefficient ( $\left.\mathrm{H}^{\prime}\right)$, on the other hand, is most affected by the appearance or disappearance of rare species and is, therefore, more effective in detecting small changes in the weed community using equation $6: H^{\prime}=\sum(p i * i n(p i))$.

Where $\mathrm{D}=$ Simpson diversity coefficient; $\mathrm{H}^{\prime}=$ Shannon-Weiner diversity coefficient (based on density); ni = number of individuals of species "i"; $\mathrm{N}=$ total number of individuals in the sample; $\mathrm{pi}=$ proportion of individuals in the sample belonging to species " $i$ ".

The SEP coefficient is an index capable of inferring about the sustainability of managements applied to productive systems from static data, being obtained by dividing the Shannon-Weiner diversity coefficient calculated based on species dominance by the same coefficient obtained for the species respective densities using equation 7, where: $S E P=H d^{\prime} H$.

Subsequently, the treatments were compared with each other by Jaccard's asymmetric binary similarity coefficient. Based on the Jaccard coefficients (eq. 8), the similarity matrix was prepared and, from this, the dissimilarity matrix (1-similarity - eq. 9) was obtained, using the following formula (Concenço et al., 2013): eq. (5): $J=\frac{c}{a+b+c}$; eq. (6): $D i=1-J$.

Where $\mathbf{J}=$ Jaccard similarity coefficient; $\mathrm{a}=$ number of species in treatment "a"; b: number of species in area "b"; c = number of species common to areas "a" and "b"; and Di: dissimilarity. The hierarchical grouping was obtained from the distance matrix (dissimilarities) (Sneath and Sokal, 1973) using the unweighted pair method with arithmetic mean (UPGMA) (Sneath and Sokal, 1973). Cluster validation must be carried out using the cophenetic correlation coefficient, obtained by Pearson linear correlation between the cophenetic and the original distance matrix (Sokal and Rohlf, 1962).

The analyzes were performed using software $\mathrm{R}(\mathrm{R}$ Core Team, 2016). The commands provided by the packages were used: Plyr, Vegan, Hmisc, Cairo, and ExpDes. The formulas and procedures described, both for sampling the areas and describing the communities, and grouping the species, followed the recommendations by Barbour et al. (1998) for synecological analysis.

\section{Results and Discussion}

There was a difference between treatments in absolute infestation levels, both for the number and the weed dry mass (Figure 2). The cultivation of cowpea (T2) in the off-season represented the second-largest weed dry mass. Even though cowpea produces a high volume of dry matter and soil cover, this material has a low C:N ratio (Azevedo and Spehar, 2002) and rapid degradation, reducing efficiency in weed plant control.

However, based on this research data, the use of cowpea may be a viable alternative, but it needs further studies to complete this information. 


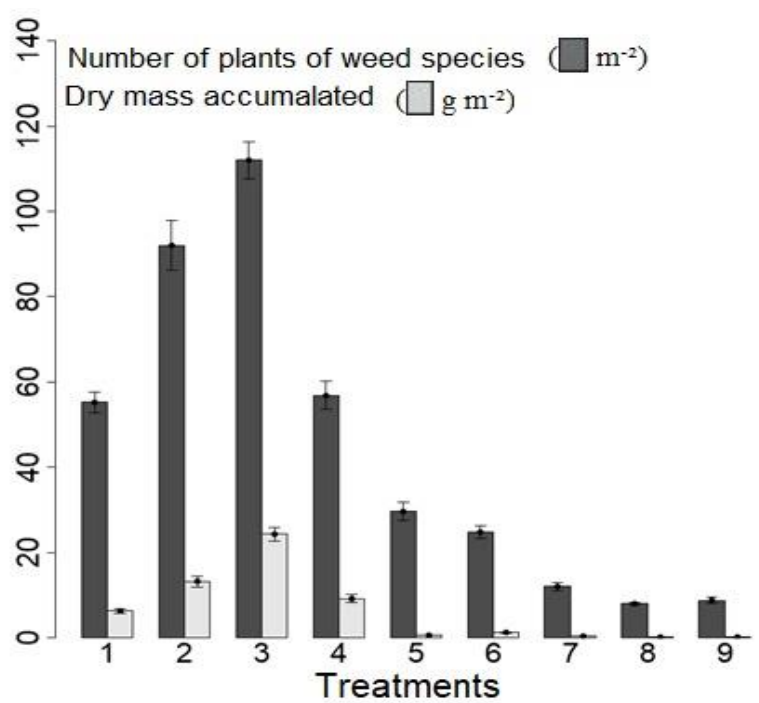

Figure 2. Number of weeds $\left(\mathrm{m}^{2}\right)$ and dry matter of the aerial part $\left(\mathrm{g} \mathrm{m}^{-2}\right)$ of weeds in soybean crop after annual crops and pasture, Dourados, MS. T1: intercropping; T2: cowpea; T3: single corn; T4: Brachiaria for 1 year; T5: for two years; T6: for three years; T7: for four years; T8: for five years; T9: for six years.

The treatment related to the cultivation of single corn (T3) showed the highest number and dry mass of weed plants. This finding can be explained by the vegetation cover not being evenly distributed in the area since the highest concentration of the corn vegetable mass is present in the stem (Andrade, 1995) and can favor the weeds multiplication (Oliveira Neto et al., 2010).

According to Vidal et al. (2005), corn under sowing conditions in a cold period can take up to 50 DAE to reach the V3 stage in certain regions of Rio Grande do Sul, and in general, the delay in closing the rows favors weed incidence. It is worth mentioning that the quantity and quality of the light that reaches the seeds in soils can favor the greater occurrence of weeds, mainly compared to soils with straw on the surface (Rizzardi et al., 2006).

However, when corn is intercropped with Brachiaria, there is a reduction of approximately $50 \%$ in absolute weed infestation. Similar results were observed by Melo et al. (2019), who, when comparing the cultivation of Brachiaria and single corn with different spacing preceding the soybean, found a greater reduction in the absolute weed number and less developed, reducing the weed population in the subsequent soybean crop.

According to Freitas et al. (2005), the intercropping between crops and forage species can promote the suppression of emergence and development of weeds. This reference corroborates the data obtained since using Brachiaria as a predecessor crop and, when grown in association with corn, reduced the weed emergence.

The treatment consisting of Brachiaria for one year (T4) showed median absolute weed infestation compared to the other treatments. It is worth mentioning that only one year of single Brachiaria in the off-season showed greater infestation than the corn-Brachiaria intercropping. In fact, it is observed that the longer the period of pasture cultivation (T8 and T9), the greater the reductions in the values of absolute number and dry mass compared to T4.

It is noted that treatments with different years of use of single Brachiaria as pasture as in T5, T6; T7; T8; T9, presented lower numbers of weeds in the area, and the dry mass of these species had a greater reduction after four years of cultivation (T7, T8, and T9). This effect is reinforced by the weed dry mass reduction compared to treatments $\mathrm{T} 2$ and $\mathrm{T} 3$.

Calonego et al. (2012) report that the $\mathrm{C}: \mathrm{N}$ ratio of corn and Brachiaria is equal to or greater than 30 , with high persistence in the soil, reaching up to 135 days after harvest. For this, it is possible to emphasize the importance of both species to weed control. In contrast, single corn did not show the same efficiency.

Other authors also evidence the benefits of the cornBrachiaria intercropping as a tool in integrated weed management (Jakelaitis et al., 2004; Concenço et al., 2012). These findings are corroborated by Seidel et al. (2015), emphasizing higher dry matter production from the corn-Brachiaria intercropping than single corn.

Regarding the weed diversity (Table 1), in the areas with corn-Brachiaria intercropping in the off-season, it was observed that the total number of weeds decreased approximately $50 \%$, with four times less dry mass than with single corn. Among the species found in this treatment, it is noted that Amaranthus Viridis and Commelina benghalensis had the highest relative importance value (I.V\%), 33.23\% and 24.83\%, respectively. A. Viridis showed the relative density (59.42) and the highest frequency (26.67\%), while C. benghalensis had the highest dominance, $64.93 \%$ (Table 1).

The cowpea cultivation provided the second-largest infestation, totaling 115 plants $\mathrm{m}^{-2}$ and an accumulated dry mass of $16.56 \mathrm{~g} \mathrm{~m}^{-2}$. Note that A. Viridis and $C$. echinatus are the weed species that presented the highest importance values, $64.50 \%$ and $17.81 \%$, respectively. In general, A. Viridis presented the highest density value, frequency, and dominance.

Single corn cultivation in off-season showed the highest infestation number (140 plants) and weed dry mass $(30.37 \mathrm{~g})$. Four weed species showed similar importance values: E. crusgalli, C. echinatus, A. Viridis, and L. nepetifolia. E. crusgalli had the highest dominance (44.58\%), and the species C. echinatus and L. nepetifolia had a similar density value, $31.43 \%$ and $37.14 \%$, respectively, and a frequency value equal to $21.43 \%$. A. Viridis presented $18.57 \%$ density, $24.43 \%$ frequency, and $25.95 \%$ dominance.

In the treatment with only one year of Brachiaria before soybean, it was observed less weed species diversity compared to the treatments having cornBrachiaria intercropping (T1), cowpea (T2), and single 
corn (T3). It was also noted that $C$. echinatus and $A$. Viridis are the species with the highest importance value, $68.48 \%$ and $16.12 \%$, respectively. The species $C$. echinatus, in general, has higher density, frequency, and dominance values.

The treatment with two years of Brachiaria used as pasture showed a decrease of approximately half of the total weeds, compared to the cultivation of only one year in the autumn-winter harvest. C. echinatus obtained the highest importance value $(38.73 \%)$ concerning weed species, similar to what occurred in the T4 treatment, followed by Brachiaria (35.32\%). However, C. echinatus presented the highest density value $(48.65 \%)$ and (33.3\%), the Brachiaria was dominant, with $51.32 \%$.

Table 1. Species, number of plants, dry mass of plants, density (DE), frequency (FR), dominance (DO) and importance value (IV) indices of the weed community in soyben crop after annual crops and pasture.

\begin{tabular}{|c|c|c|c|c|c|c|c|}
\hline Treatement & Species & $\begin{array}{c}\text { Number of plants } \\
\left(\mathrm{m}^{2}\right)\end{array}$ & $\begin{array}{c}\text { Dry mass } \\
\left(\mathrm{g} \mathrm{m}^{-2}\right)\end{array}$ & $\begin{array}{l}\mathrm{DE} \\
(\%)\end{array}$ & $\begin{array}{l}\text { FR } \\
(\%)\end{array}$ & $\begin{array}{l}\mathrm{DO} \\
(\%)\end{array}$ & $\begin{array}{l}\text { IV } \\
(\%) \\
\end{array}$ \\
\hline \multirow{7}{*}{$\mathrm{T} 1$} & Brachiaria ruziziensis & \multirow{7}{*}{69} & \multirow{7}{*}{7,86} & 2.9 & 13.33 & 3.3 & 6.51 \\
\hline & Digitaria sanguinalis & & & 13.04 & 6.67 & 2.03 & 7.25 \\
\hline & Cenchrus echinatus & & & 8.7 & 13.33 & 12.83 & 11.62 \\
\hline & Amarantus viridis & & & 59.42 & 26.67 & 13.6 & 33.23 \\
\hline & Leonotis nepetifolia & & & 4.35 & 20 & 1.4 & 8.58 \\
\hline & Euphorbia heterophylla & & & 8.7 & 13.33 & 1.91 & 7.98 \\
\hline & Commelina benghalensis & & & 2.9 & 6.67 & 64.93 & 24.83 \\
\hline \multirow{5}{*}{$\mathrm{T} 2$} & Digitaria sanguinalis & \multirow{5}{*}{115} & \multirow{5}{*}{16,56} & 0.87 & 10 & 0.48 & 3.78 \\
\hline & Cenchrus echinatus & & & 26.96 & 20 & 6.46 & 17.81 \\
\hline & Amarantus viridis & & & 62.61 & 40 & 90.88 & 64.5 \\
\hline & Leonotis nepetifolia & & & 8.7 & 20 & 2.11 & 10.27 \\
\hline & Euphorbia heterophylla & & & 0.87 & 10 & 0.06 & 3.64 \\
\hline \multirow{8}{*}{$\mathrm{T} 3$} & Echinochloa crusgalli & \multirow{8}{*}{140} & \multirow{8}{*}{30,37} & 9.29 & 7.14 & 44.58 & 20.34 \\
\hline & Cenchrus echinatus & & & 31.43 & 21.43 & 13.83 & 22.23 \\
\hline & Amarantus viridis & & & 18.57 & 21.43 & 25.95 & 21.98 \\
\hline & Leonotis nepetifolia & & & 37.14 & 21.43 & 4.05 & 20.87 \\
\hline & Euphorbia heterophylla & & & 0.71 & 7.14 & 0.99 & 2.95 \\
\hline & Bidens pilosa & & & 0.71 & 7.14 & 0.2 & 2.68 \\
\hline & Euphorbia hirta & & & 0.71 & 7.14 & 0.03 & 2.63 \\
\hline & Commelina benghalensis & & & 1.43 & 7.14 & 10.37 & 6.31 \\
\hline \multirow{4}{*}{$\mathrm{T} 4$} & Cenchrus echinatus & \multirow{4}{*}{71} & \multirow{4}{*}{11,44} & 76.06 & 36.36 & 93.01 & 68.48 \\
\hline & Amarantus viridis & & & 15.49 & 27.27 & 5.59 & 16.12 \\
\hline & Leonotis nepetifolia & & & 5.63 & 18.18 & 0.52 & 8.11 \\
\hline & Commelina benghalensis & & & 2.82 & 18.18 & 0.87 & 7.29 \\
\hline \multirow{6}{*}{$\mathrm{T} 5$} & Brachiaria ruziziensis & \multirow{6}{*}{37} & \multirow{6}{*}{0,76} & 32.43 & 22.22 & 51.32 & 35.32 \\
\hline & Echinochloa crusgalli & & & 5.41 & 11.11 & 1.32 & 5.95 \\
\hline & Cenchrus echinatus & & & 48.65 & 33.33 & 34.21 & 38.73 \\
\hline & Amarantus viridis & & & 8.11 & 11.11 & 5.26 & 8.16 \\
\hline & Emilia sonchifolia & & & 2.7 & 11.11 & 2.63 & 5.48 \\
\hline & Commelina benghalensis & & & 2.7 & 11.11 & 5.26 & 6.36 \\
\hline \multirow{6}{*}{ T6 } & Brachiaria ruziziensis & \multirow{6}{*}{31} & \multirow{6}{*}{1,57} & 61.29 & 37.5 & 77.07 & 58.62 \\
\hline & Paspalum conspersum & & & 6.45 & 12.5 & 0.64 & 6.53 \\
\hline & Amarantus viridis & & & 6.45 & 12.5 & 0.64 & 6.53 \\
\hline & Ipomoea grandifolia & & & 3.23 & 12.5 & 18.47 & 11.4 \\
\hline & Euphorbia heterophylla & & & 3.23 & 12.5 & 2.55 & 6.09 \\
\hline & Euphorbia hirta & & & 19.35 & 12.5 & 0.64 & 10.83 \\
\hline \multirow{3}{*}{$\mathrm{T} 7$} & Brachiaria ruziziensis & \multirow{3}{*}{15} & \multirow{3}{*}{0,49} & 80 & 50 & 81.63 & 70.54 \\
\hline & Euphorbia heterophylla & & & 13.33 & 33.33 & 16.33 & 21 \\
\hline & Commelina benghalensis & & & 6.67 & 16.67 & 2.04 & 8.46 \\
\hline & Brachiaria ruziziensis & & & 70 & 66.67 & 86.96 & 74.54 \\
\hline $\mathrm{T} 8$ & Richardia brasiliensis & 10 & 0,23 & 20 & 16.67 & 8.7 & 15.12 \\
\hline & Euphorbia hirta & & & 10 & 16.67 & 4.35 & 10.34 \\
\hline & Brachiaria ruziziensis & & & 9.09 & 14.29 & 4.17 & 9.18 \\
\hline & Cenchrus echinatus & & & 45.45 & 14.29 & 33.33 & 31.02 \\
\hline T9 & Leonotis nepetifolia & 11 & 0,24 & 18.18 & 28.57 & 8.33 & 18.36 \\
\hline & Euphorbia heterophylla & & & 9.09 & 14.29 & 45.83 & 23.07 \\
\hline & Commelina benghalensis & & & 18.18 & 28.57 & 8.33 & 18.36 \\
\hline
\end{tabular}

T1: intercropping; T2: cowpea; T3: single corn; T4: Brachiaria for 1 year; T5: for two years; T6: for three years; T7: for four years; T8: for five years; T9: for six years. 
In the treatment with three years of Brachiaria used as pasture, the species found in the soybean crop with the highest importance value $(58.62 \%)$ was B. ruziziensis, similar to the areas with four and five years of pasture. In these last treatments, $B$. ruziziensis was the weed with the highest importance value, $70.54 \%$ and 74.54, respectively.

The variation in species diversity between treatments with single Brachiaria as pasture is little changed. However, it is observed that the total number of weed plants declined (from 71 to 11 plants) over the years of pasture implantation preceding soybean.

It is observed that E. heterophylla, C. benghalensis, and Amaranthus ssp. were the species that appeared in six of the nine treatments. E. heterophylla was present in T1, T2, T3, T5, T6, and T9, being little affected by the soil cover shading. This occurrence may be due to its germination in deeper layers of the soil, besides the straw layer or vegetation cover breaking (Blanco, 2014).

C. benghalensis was present in T1, T3, T4, T5, T7, and $\mathrm{T} 8$ treatments, with grasses, mainly Brachiaria, as a predecessor crop. According to Blanco (2014), this species can produce viable seeds both aerial and underground, in addition to presenting better adaptation to shaded environments. Another fact is that the herbicide used in the area desiccation was glyphosate, and according to Carvalho et al. (2015), this species has a high tolerance to this herbicide.

Amaranthus ssp. appeared in T1, T2, T3, T4, and T5 treatments, although it is possible to observe that this species presence was not observed in pasture treatments. Amaranthus ssp. has C4 metabolism, which means having better development in areas with greater light (Silva and Silva, 2007). The effect of the vegetation cover provided by the Brachiaria in the pasture for several years may have suppressed this weed growth.

Silva et al. (2018) emphasize that weed species composition ranges depending on the type of management used; thus, weed species diversity may differ. The phytosociological evaluation in this study in areas with different predecessor crops allowed knowing the weed species present in these areas, understanding the occurrence of certain species, and, if necessary, can be auxiliary data to choose the appropriate herbicide.

In Figure 3, the Simpson (D) and Shannon-Weiner $\left(H^{\prime}\right)$ diversity coefficients are presented, as well as the Shannon sustainability coefficients (SEP). In simple terms, D Coefficient quantifies the probability of two individuals collected at random belonging to the same species; that is, the Simpson coefficient is mainly influenced by the occurrence of abundant species by the number of individuals (Concenço et al., 2016).
It should be noted that the $\mathrm{T} 1$ and $\mathrm{T} 2$ treatments do not show any difference; both had A. Viridis as the most frequent species with the highest density and with cornBrachiaria intercropping and cowpea as predecessor crops, respectively. However, T1 is similar to T3, T5, T6, and $\mathrm{T} 9$ treatments: single corn, Brachiaria cultivation for two years; Brachiaria cultivation for three years; and Brachiaria cultivation for six years, respectively. It is observed that in these treatments, the Simpson diversity index (D) was high, meaning that species considered to be abundant in the area were affected. T4, T7, and T8, on the other hand, have a low Simpson diversity index (D) compared to the other treatments.

The Shannon-Weiner coefficient ( $\left.\mathrm{H}^{\prime}\right)$ is quantified employing sporadic individuals, that is, the occurrence of rare species influences it, and in the T1, T3, T5, T6, and T9 treatments, changes are detected in the weed community, meaning that species with less occurrence and/or presence in the area were affected. Pasture treatments preceding soybeans in different years contribute to the disappearance of certain species, especially those considered difficult to control from an agronomic perspective. It is expected that over time this management will promote weed control.

The SEP sustainability index showed no significant disturbances in $\mathrm{T} 1, \mathrm{~T} 3, \mathrm{~T} 5, \mathrm{~T} 7$, and $\mathrm{T} 9$ treatments. However, (McManus e Pauly, 1990) emphasizes that when interpreting SEP sustainability for agricultural areas, it is impossible to state which is ideal but to analyze which species are disappearing or appearing in these treatments with SEP not close to "one" (Concenço et al., 2016).

The dissimilarity (Figure 4), aiming to identify how the predecessor crop affects the weed community, obtained by the UPGMA method, generated a coefficient of cophenetic ratio equivalent to $81 \%$. The analysis showed only two clusters of the area at the threshold level, based on the average of the original dissimilarity matrix of Jaccard: in the first group T6 and T8, and the other treatments in the second group.

The T6 and T8 treatments differ by the presence of $I$. grandifolia and $R$. brasiliensis, respectively, which may have been introduced with intercropped cultivation of Brachiaria and corn in the 2019 off-season via impurities of Brachiaria seeds. It was observed that the cluster analysis is not directly related to the level of absolute infestation, shown in Figure 2. However, it is possible to observe a moderate relationship with the phytosociological table (Table 1), considering the presence or absence and not the number of weed species. Also, the residual effect of the prolonged Brachiaria cultivation on reducing the number of weed species concerning the areas with crop rotation was noticed. 


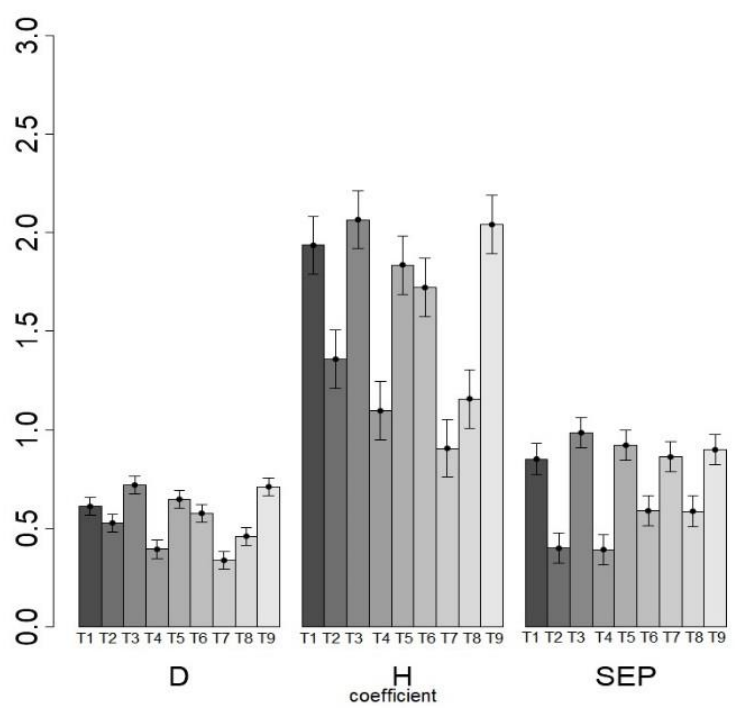

Figure 3. Simpson (D) and Shannon-Weiner (H) diversity coefficients and SEP sustainability coefficient of weeds in soybean crop after annual crops and pasture, Dourados, MS. T1: intercropping; T2: cowpea; T3: single corn; T4: Brachiaria for 1 year; T5: for two years; T6: for three years; T7: for four years; T8: for five years; T9: for six years.

\section{Conclusions}

The corn-Brachiaria intercropping reduces the number and diversity of weed plants in the successor crop.

The use of isolated Brachiaria as pasture promotes a significant reduction in the weed community with increasing cultivation years in the successor crops.

\section{Authors' Contribution}

Ricardo Fachinelli: Conception, design, data acquisition, data analysis and interpretetion; Thais Stradioto Melo: data acquisition, data analysis and interpretetion; Denise Prevedel Capristo: conception, design, data acquisition; Hadassa Kathyuci Antunes de Abreu: data acquisition; Gessí Ceccon: guidance, conception, design.

\section{Bibliographic References}

Andrade, F.H. 1995. Analysis of growth and yield of maize, sunflower and soybean grown at Balcarce, Argentina. Field Crops Research, 41(1), 1-12. DOI: 10.1016/03784290(94)00107-N.

Azevedo, D.M.P., Spehar, C.R. 2002. Decomposição da palhada de culturas para plantio no período de safrinha em solos de tabuleiros costeiros. Teresina: Embrapa Meio Norte, Embrapa Meio Norte. Comunicado Técnico, 147. 8 p.

Barbour, M.G., Burk, J.H., Pitts, D. 1998. Terrestrial plant ecology, third edition. Menlo Park, Benjamin Cummings.

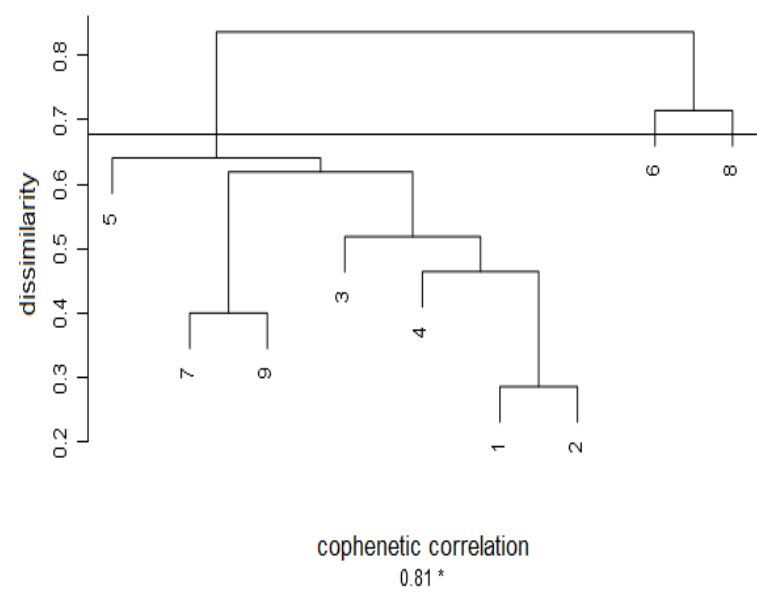

Figure 4. Multivariete cluster analysis for weeds in soybean crop after annual crops and pasture, Dourados, MS. The cutoff point for cluster formation was obtained by arithmetic mean method of te Jaccard dissimilarity matrix, disregarding the intersections between the same areas. Clustering was established based on the UPGMA method. T1: intercropping; T2: cowpea; T3: single corn; T4: Brachiaria for 1 year; T5: for two years; T6: for three years; T7: for four years; T8: for five years; T9: for six years.

Blanco, F.M.G. 2014. Classificação e mecanismo de sobrevivência de plantas daninhas, first ed. In: Monqueiro, P.A. (Ed.) Aspectos da Biologia e Manejo das Plantas Daninhas. São Carlos, Rimas, p. 33-60.

Calonego, J.C., Gil, F.C., Rocco, V.F., Santos, E.A. 2012. Persistência e liberação de nutrientes da palha do milho, braquiária e labe-labe. Bioscience Journal, 28(5), 770-781.

Carvalho, F.P., São José, R.H., Lopes, L.C.M., Ronchi, C.P. 2015. Controle de trapoeraba com diferentes formulações de glyphosate. Revista Brasileira de Herbicidas, 14(3), 194-199. DOI: $10.7824 /$ rbh.v14i3.419.

Concenço, G., Leme Filho, J.R.A., Silva C.J., Marques, R.F., Silva, L.B.X., Correia I.V.T. 2016. Weed occurrence in sugarcane as function of variety and ground straw management. Planta Daninha, 34(2), 219-228. DOI: 10.1590/S010083582016340200003 .

Concenço, G., Tomazi, M., Correia, I.V.T., Santos, S.A., Galon, L. 2013. Phytosociological surveys: tools for weed science? Planta Daninha, 31(2), 469-482.

Concenço, G., Ceccon, G., Fonseca, I.C., Leite, L.F., Schwerz, F., Correia, I.V.T. 2012. Weeds infestation in corn intercropped with forages at different planting densities. Planta Daninha, 30(4), 721-728. DOI: 10.1590/S0100-83582012000400005.

Freitas, F.C.L., Ferreira, L.R., Ferreira, F.A., Santos, M.V., E.L., Cardoso, A.A., Jakelaitis, A. 2005. Formação de pastagem via consórcio de Brachiaria brizantha com o milho para silagem no sistema de plantio direto. Planta Daninha, 23(1), 49-58. DOI: 10.1590/S0100-83582005000100007.

Gontijo Neto, M.M., Viana, M.C.M., Alvarenga, R.C., Santos, E.A., Simão, E.P., Campanha, M.M. 2014. Sistemas de integração lavoura-pecuária-floresta em Minas Gerais. Boletim 
de Indústria Animal, 71(2), 183-191. DOI: 10.17523/bia.v71n2p183.

Jakelaitis, A., Silva, A.A., Ferreira, L.R., Silva, A.F., Freitas, F.C.L. 2004. Manejo de plantas daninhas no consórcio de milho com capim-braquiária (Brachiaria decumbens). Planta Daninha, 22(4), 553-560. DOI: 10.1590/S010083582004000400009 .

Martins D., Gonçalves, C.G., Silva Junior, A.C. 2016. Coberturas mortas de inverno e controle químico sobre plantas daninhas na cultura do milho. Revista Ciência Agronômica, 47(4), 649-657.

McManus, J., Pauly, D. 1990. Measuring ecological stress: variations on a theme by R.M. Warwick. Marine Biology, 106(2), 305-309. DOI: 10.1007/BF01314814.

Melo, T.S., Makino, P.A., Ceccon, G. 2019. Weed diversity in corn with different plant arrangement patterns grown alone and intercropped with palisade grass. Planta daninha, 37, e019195957. DOI: 10.1590/s0100-83582019370100103.

Nordi, J.C., Landgraf, P.R.C. 2009. Composição florística e fitossociologia da comunidade infestante em gramado de Paspalum notatum Flügge no laboratório de botânica da Universidade de Taubaté, SP. Revista Biociências, 15(2), 106114.

Oliveira Neto, A.M., Constantin, J., Oliveira Jr., R.S., Guerra, N., Dan, H.A., Alonso, D.G., Blainski, E., Santos, G. 2010. Estratégias de manejo de inverno e verão visando ao controle de Conyza bonariensis e Bidens pilosa. Planta Daninha, 28(spe), 1107-1116. DOI: $\quad 10.1590 /$ S010083582010000500018.

Pandeya, S.C., Puri, G.S., Singh, J.S. 1968. Research methods in plant ecology. New York, Asia Publishing House.

R Core Team. 2016. A language and environment for statistical computing. R Foundation for Statistical Computing, Vienna. http://www.R-project.org (Acecessed February 18, 2019).
Rizzardi, M.A., Silva, L.F., Vargas, L. 2006. Controle de plantas daninhas em milho em função de quantidades de palha de nabo forrageiro. Planta Daninha, 24(2), 263-70.

Santos, H.G., Jacomine, P.K.T., Anjos, L.H.C., Oliveira, V.A., Lumbreras, J.F., Coelho, M.R., Almeida, J.A., Araujo Filho, J.C., Oliveira, J.B. Cunha, T.J.F. 2018. Sistema Brasileiro de Classificação de Solos, fifth ed. Brasília, DF: Embrapa.

Seidel, E.P., Mattias, V., Mattei, E, Corbari, F. 2015. Produção de matéria seca e propriedades físicas do solo na consorciação milho e braquiária. Scientia Agraria Paranaensis, 14(1), 18-24. DOI: $10.18188 /$ sap.v14i1.8226.

Silva, A.A., Silva, J.F. 2007. Tópicos em manejo de plantas daninhas, first ed. Viçosa, UFV.

Silva, D.A., Albuquerque, J.A.A., Alves, J.M.A., Rocha, P.R.R., Medeiros, R.D., Finoto, E.L., Menezes, P.H.S. 2018. Characterization of weed in rotated area of maize and cowpea in direct planting. Scientia Agropecuaria, 9(1), 7-15. DOI: 10.17268/sci.agropecu.2018.01.01.

Sneath, P.H., Sokal, R.R. 1973. Numerical taxonomy: The principles and practice of numerical classification, first ed. San Francisco, W.H. Freeman.

Sodré Filho, J., Cardoso, A.N., Carmona, R., Carvalho, A.M. 2004. Fitomassa e cobertura do solo de culturas de sucessão ao milho na região do Cerrado. Pesquisa Agropecuária Brasileira, 39(4), 327-334. DOI: 10.1590/S0100-204X2004000400005.

Sokal, R.R., Rohlf, F.J. 1962. The comparison of dendrograms by objective methods. Taxon, 11(2), 33-40. DOI: $10.2307 / 1217208$

Vidal, R.A., Fleck, N.G., Merotto J.R.A. 2005. Período anterior ao dano no rendimento econômico (PADRE): nova abordagem sobre os períodos de interferência entre plantas daninhas e cultivadas. Planta Daninha, 23(3), 387-396. DOI: 10.1590/S0100-83582005000300001 